\section{Pengaruh Topografi dan Umur Ayam yang Berbeda terhadap Ketebalan Kerabang dan Ph Telur Ayam Ras Petelur}

\author{
Andika Dony Wijaya \\ Munir \\ Muh. Jurhadi Kadir
}

\begin{abstract}
Abstrak. Penelitian ini bertujuan untuk mengetahui pengaruh topografi dan umur ayam ras yang berbeda terhadap berat telur dan haugh unit. Penelitian dilaksanakan pada bulan Agustus 2018, pengambilan data di ambil dari Kelurahan Amparita Kecamatan Tellu Limpoe Kabupaten Sidenreng Rappang, Desa Mario Kecamatan Kulo Kabupaten Sidenreng Rappang dan Desa Kaluppang Kecamatan Maiwa Kabupaten Enrekang. Penelitian menggunakan telur sebanyak 135 butir ayam ras. Penelitian menggunakan Rancangan Acak Kelompok Faktorial dengan dengan tiga tahap perlakuan dan tiga kali pengulangan yaitu Faktor A (Umur ayam 30 minggu, umur ayam 50 minggu, dan umur ayam 70 minggu) kemudian Faktor $B$ (Topografi dataran rendah, sedang, dan tinggi). Perlakuan pengaruh topografi dan umur ayam ras petelur menunjukan bahwa umur ayam yang berbeda tidak berpengaruh nyata $(P>0,05)$ terhadap ketebalan kerabang telur sedangkan topografi sangat berpengaruh nyata terhadap ketebalan kerabang telur $(P<0,01)$. Umur ayam ras yang berbeda berpengaruh nyata $(P<0,05)$ terhadap $\mathrm{pH}$ telur, dan topografi yang berbeda berpengaruh sangat nyata $(P<0.01)$ terhadap ph telur.

Kata Kunci: Ayam Ras Petelur, Topografi, Umur ayam, Ketebalan Kerabang dan $\mathrm{pH}$ Telur.
\end{abstract}

\section{Pendahuluan}

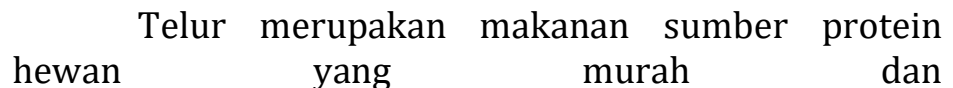
mudah untuk didapatkan oleh masyarakat Indonesia. Tel ur memiliki kandungan gizi lengkap mulai dari protein, lemak, vitamin, dan mineral. Meskipun demikian telur juga mudah mengalami penurunan kualitas yang disebabkan oleh kontaminasi mikroba, kerusakan secara fisik serta penguapan air dan gas-gas karbondioksida, amonia, nitrogen, dan hidrogen sulfida dari dalam telur (Romanoff dan Romanoff, 1963). Semakin lama telur disimpan penguapan yang terjadi akan membuat bobot telur menyusut dan putih telur menjadi lebih encer (Buckle et al.,1987). Selain dipengaruhi oleh lama penyimpanan, penguapan ini juga dipengaruhi oleh suhu, kelembaban relatif dan kualitas kerabang telur (Yuwanta, 2010). Kerabang telur merupakan lapisan luar telur yang melindungi telur dari penurunan kualitas baik disebabkan oleh kontaminasi mikroba, kerusakan fisik, maupun penguapan. Salah satu yang mempengaruhi kualitas kerabang telur adalah umum ayam, semakin meningkat umur ayam kualitas kerabang semakin menurun, kerabang telur semakin tipis, warna kerabang semakin memudar, dan berat telur

\section{BIONATURE}

\author{
p-ISSN 1411 - 4720 \\ e-ISSN 2654 - 5160
}

Abstract. This study aims to determine the effect of topography and age of different breeds of chickens on egg weight and haugh unit. The study was conducted in August 2018, data collection was taken from Amparita Village, Tellu Limpoe District, Sidenreng Rappang Regency, Mario Village Kulo District, Sidenreng Rappang District and Kaluppang Village,

Maiwa District, Enrekang District. The study used 135 eggs as eggs. The study used a Factorial Randomized Block Design with three stages of treatment and three repetitions, namely Factor A (Age of chicken 30 weeks, age of chicken 50 weeks, and age of chicken 70 weeks) then Factor $B$

(Topography of lowland, medium and high). The treatment of topographic influence and age of laying chicken showed that the age of different chickens had no significant effect $(P>0.05)$ on eggshell thickness while the topography greatly affected eggshell thickness $(P<0.01)$.

Different age of race chicken has significant effect $(P<0.05)$ on egg $p H$, and different topography has very significant effect $(P<0.01)$ on egg ph

Keywords: Laying Chicken, Topography, Chicken Age, Shell Thickness and Egg pH.

Andika Dony Wijaya

Universitas Muhammadiyah Parepare Indonesia

Munir

Universitas Muhammadiyah Parepare Indonesia

Muh. Jurhadi Kadir

Universitas Muhammadiyah Parepare Indonesia 
semakin besar (Yuwanta, 2010).

Daerah sulawesi selatan merupakan daerah sentra ayam petelur, sistem penjualan telur berbeda dengan daerah lain dimana telur ayam ras di jual dengan satuan rak bukan satuan $\mathrm{Kg}$, sehingga target yang di capai hanya kuantitas tanpa memperhatik kualitas telur, namun secara umum di indonesia penghitungan satuan telur adalah kg sehingga di daerah lain selain pulau sulawesi target pencapaian produksi adalah berat dan jumlah telur.

Dalam penelitian ini penulis akan mengamati ketebalan kerabang dan $\mathrm{Ph}$ telur yang bersumber dari peternakan didataran rendah dan di dataran tinggi serta umur ayam yang berbeda, yang diharapkan dari penelitian ini dapat membuka pengetahuan kita dari hasil yang kita temukan nanti, berdasarkan ulasan di atas saya mengangkat judul pengaruh topografi dan umur ayam berbeda terhadap ketebalan kerabang dan $\mathrm{pH}$ telur ayam ras petelur dalam penelitian ini.

\section{Metode Penelitian}

\section{Waktu dan Tempat Penelitian}

Penelitian ini di laksanakan pada bulan Agustus 2018 di Kabupaten Sidenreng Rappang dan Kabupaten Enrekang, dan dilanjutkan pengujian di Laboratorium Fakultas Pertanian Peternakan dan Perikanan Universitas Muhammadiyah Parepare.

\section{Rancangan Penelitian}

Penelitian ini menggunakan Rancangan Acak Kelompok (RAK) pola faktorial. Dimana faktor $A$ yaitu umur ayam (A1= 30 minggu, $A 2=50$ minggu, $A 3=70$ minggu). Sedangkan faktor $B$ yaitu Topografi. Sehingga menghasilkan formasi sebagai berikut:

A1R : Umur ayam 30 minggu + dataran rendah

A2R : Umur ayam 50 minggu + dataran rendah

A3R : Umur ayam 70 minggu + dataran rendah

A1S : Umur ayam 30 minggu + dataran sedang

A2S : Umur ayam 50 minggu + dataran sedang

A3S : Umur ayam 70 minggu + dataran sedang

A1T : Umur ayam 30 minggu + dataran tinggi

A2T : Umur ayam 50 minggu + dataran tinggi

A3T : Umur ayam 70 minggu + dataran tinggi

Data yang diperoleh di hitung dengan menggunakan Rancangan Acak Kelompok pola faktorial dengan model matematika sebagai berikut:

Keterangan:

$$
H i j k=\pi+K i+P j+P k+(P j x P k)+e i j k
$$

Hijk : Hasil akibat perlakuan ke-j dan perlakuan ke-k pada kelompok ke - i

$\Pi \quad$ : Nilai tengah umum

$\mathrm{Ki} \quad$ : Pengaruh kelompok ke-i

$\mathrm{Pj} \quad$ : Pengaruh faktor perlakuan ke-j

$\mathrm{Pk} \quad$ : Pengaruh faktor perlakuan ke-k

$\mathrm{Pj} \times \mathrm{Pk} \quad$ : Interaksi perlakuan ke-j dan perlakuan ke-k

Eijk : Eror akibat perlakuan ke-j dan perlakuan ke-k pada kelompok ke-i

I $\quad: 1,2, \ldots ., \mathrm{k}(\mathrm{k}=$ kelompok $)$

J $\quad: 1,2, \ldots ., \mathrm{p}$ ke-1 $(\mathrm{p}=$ perlakuan ke- 1$)$

$\mathrm{K} \quad: 1,2 \ldots \mathrm{p} \mathrm{ke}-2(\mathrm{p}=$ perlakuan ke-2) 
Apabila terdapat pengaruh yang nyata maka masing - masing perlakuan dilanjutkan dengan uji beda nyata (Durcan Multiple Range Test) dengan bantuan program SPSS Versi.1.6.

\section{Hasil dan Pembahasan}

Rata-rata ketebalan kerabang telur dan $\mathrm{pH}$ telur ayam ras dengan umur ayam yang bebeda dan topografi yang berbeda dapat dilihat pada tabel 1. Rata-rata ketebalan kerabang (mm) dan kadar $\mathrm{pH}$ telur ayam ras dengan topografi dan umur berbeda.

\section{Tabel 1. Rata-Rata Ketebalan Kerabang (Mm) dan Kadar Ph Telur Ayam Ras dengan Topografi dan Umur Berbeda}

\begin{tabular}{|c|c|c|}
\hline \multirow{2}{*}{ Perlakuan } & \multicolumn{2}{|c|}{ Parameter } \\
\cline { 2 - 3 } & $\begin{array}{c}\text { Ketebalan } \\
\text { Kerabang(mm) }\end{array}$ & Kadar pH \\
\hline A1 & 0,42 & $6,88^{\mathrm{a}}$ \\
\hline A2 & 0,43 & $7,03^{\mathrm{b}}$ \\
\hline A3 & 0,41 & $7,04^{\mathrm{b}}$ \\
\hline R & $0,38^{\mathrm{a}}$ & $6,83^{\mathrm{a}}$ \\
\hline S & $0,42^{\mathrm{b}}$ & $6,97^{\mathrm{b}}$ \\
\hline T & $0,47^{\mathrm{b}}$ & $7,15^{\mathrm{b}}$ \\
\hline
\end{tabular}

Keterangan: Superskrip yang berbeda pada baris yang sama menunjukkan perbedaan yang nyata $(\mathrm{P}<0,05)$ pada perlakuan.

\section{Ketebalan Kerabang Telur}

Berdasarkan analisis sidik ragam menunjukkan bahwa umur ayam yang berbeda tidak berpengaruh nyata terhadap ketebalan kerabang telur dapat di lihat pada gambar 1 . Sedangkan topografi berpengaruh sangat nyata terhadap ketebalan kerabang telur dapat dilihat pada gambar 2 . Interaksi antara keduaya berpengaruh nyata $(\mathrm{P}<0,05)$ terhadap ketebalan kerabang telur.

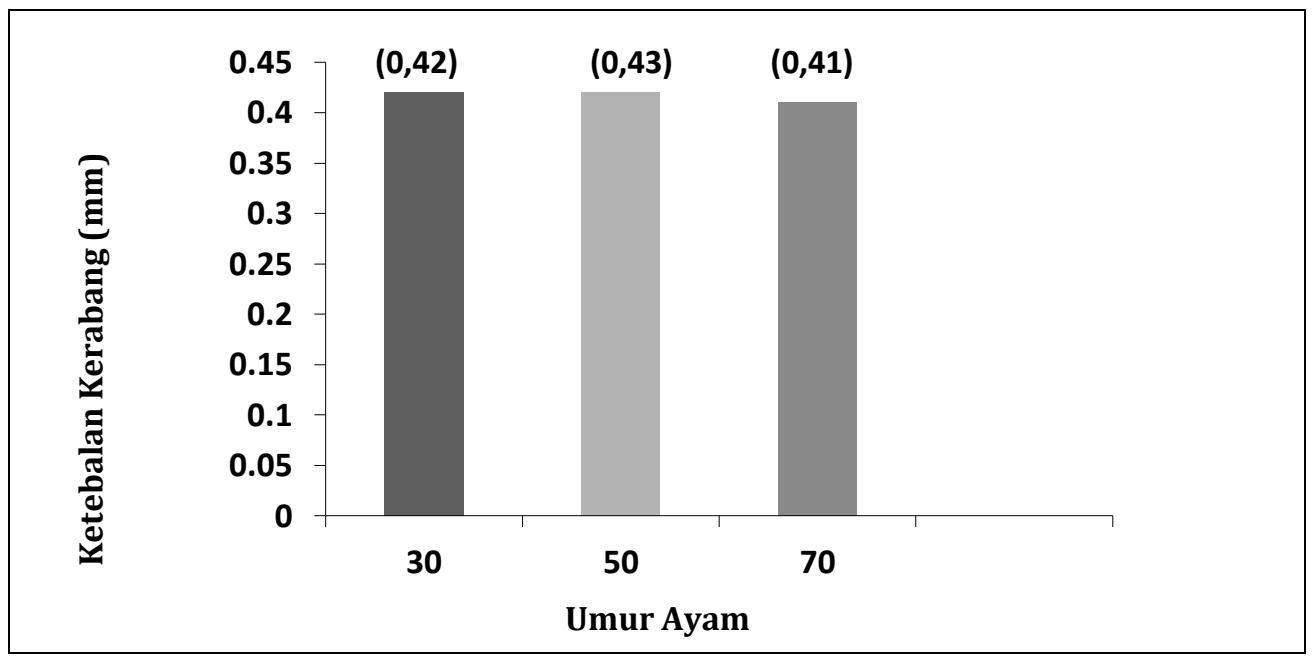

Gambar 1. Rata-Rata Ketebalan Kerabang (Mm) Telur Ayam Ras dengan Perlakuan Umur yang Berbeda ( $A 1=30$ Minggu, $A 2=50$ Minggu, $A 3=70$ Minggu) 
Gambar 1 menunjukkan perbedaan umur ayam ras yang berbeda tidak berpengaruh nyata $(\mathrm{P}>0,05)$ terhadap ketebalan kerabang telur. Ketebalan kerabang telur pada umur ayam yang berbeda berada berkisar antara 0,41 mm sampai dengan 0,43 mm. Ketebalan kerabang telur rata-rata tertinggi ke terendah diperoleh dari ayam umur 50 minggu(0,43 mm), 30 minggu $(0,42 \mathrm{~mm})$ dan 70 minggu $(0,41 \mathrm{~mm})$.

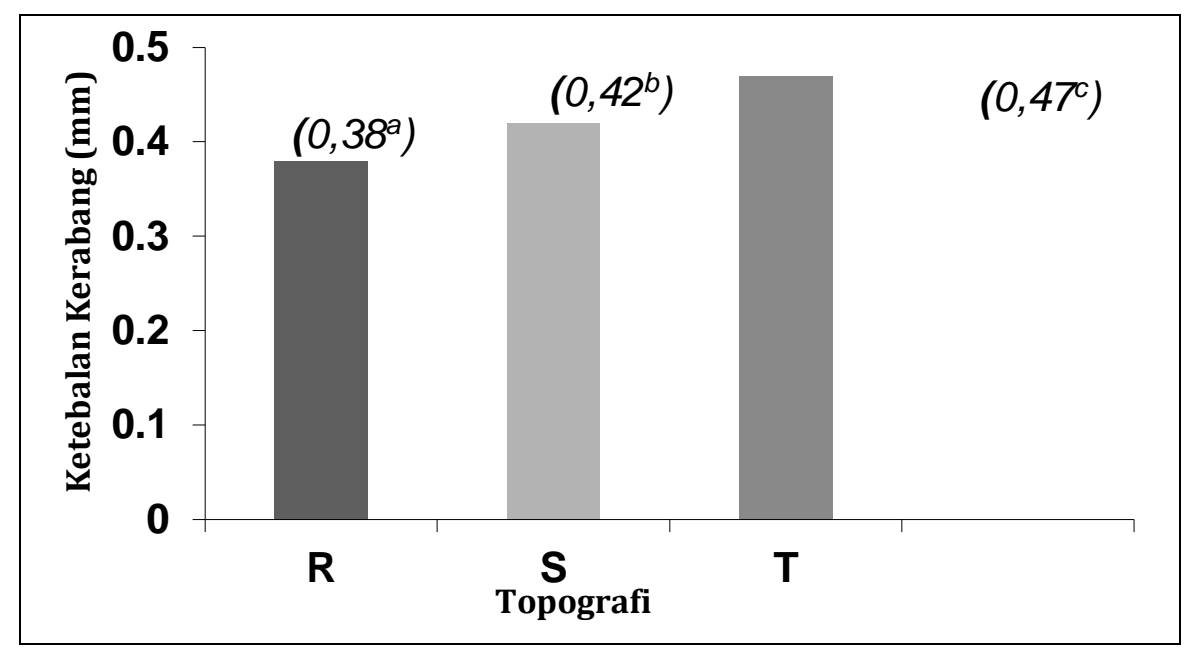

\section{Gambar 2. Rata-Rata Ketebalan Kerabang (Mm) Telur Ayam Ras dengan Perlakuan Umur yang Berbeda (R=Dataran Rendah, $S=$ Dataran Sedang, $T=$ Dataran Tinggi).}

Gambar 2 menunjukkan perbedaan topografi berpengaruh sangat nyata $(\mathrm{P}<0,01)$ terhadap ketebalan kerabang telur. Ketebalan kerabang telur pada topografi yang berbeda berada berkisar antara $0,38 \mathrm{~mm}$ sampai dengan $0,47 \mathrm{~mm}$. Ketebalan kerabang telur rata-rata tertinggi ke terendah diperoleh dari dataran rendah $(0,38 \mathrm{~mm})$, dataran sedang $(0,42 \mathrm{~mm})$ dan dataran tinggi $(0,47 \mathrm{~mm})$.

Kerabang telur merupakan lapisan luar telur yang melindungi telur dari penurunan kualitas baik disebabkan oleh kontaminasi mikroba, kerusakan fisik, maupun penguapan. Salah satu yang mempengaruhi kualitas kerabang telur adalah umur ayam, semakin meningkat umur ayam kualitas kerabang semakin menurun, kerabang telur semakin tipis, warna kerabang semakin memudar dan berat telur semakin besar (Yuwanta, 2010).

Kerabang telur memiliki sifat keras, halus, dilapisi kapur dan terikat pada bagian luar dari lapisan membran kulit luar (Winarno dan koswara, 2002. Tebal tipisnya kerabang telur dipengaruhi oleh strain ayam, umur, pakan, stress dan penyakit. Faktor umur berpengaruh nyata terhadap ketebalan kerabang telur. Hal ini sesuai dengan pernyataan Yuwanta (2010) menyatakan bahwa semakin tua umur ayam makan semakin tipis kerabang telurnya, hal ini dikarenakan ayam tidak mampu untuk memproduksi kalsium yang cukup guna memenuhi kebutuhan kalsium dalam pembentukan kerabang telur.

Kerabang telur yang tipis relatif berpori lebih banyak dan besar, sehingga mempercepat turunnya kualitas telur yang terjadi akibat penguapan (Haryono,2000). Ketebalan kulit telur ayam ras berkisar antara 0,35 mm-0,45mm (Indratiningsih, 2006). Pada penelitian ini ketebalan kerabang telur bepengaruh tehadap umur ayam, pada umur ayam umur 30 minggu memiliki ketebalan kerabang 0,42 mm, umur 50 minggu memiliki ketebalan kerabang 0,43 mm, umur 70 minggu ketebalan kerabang $0,41 \mathrm{~mm}$. Semakin tua umur ayam ketebalan kerabang semakin turun hal ini disebabkan kemampuan ayam untuk memproduksi kalsium tidak cukup.

Berat dan tebal kerabang merupakan variabel yang menentukan kualitas kerabang. Kerabang telur sebagian besar terbentuk dari kalsium karbonat $\left(\mathrm{CaCO}_{3}\right)$. Sumber Ca untuk pembentukan $\mathrm{CaCO}_{3}$ berasal dari pakan dan tulang meduler. Yuwanta (2010) menjelaskan bahwa sekitar 35\%-75\% kalsium untuk pembentukan kerabang telur berasal dari pakan, 
sedangkan kalsium yang bersumber dari tulang meduler akan digunakan bila kalsium dari pakan untuk kalsifikasi tidak mencukupi.

Kalsium dari tulang meduler bersifat terbatas, oleh karena itu bila suhu tinggi dan konsumsi pakan menurun maka kalsium yang dibutuhkan untuk pembentukan kerabang akan berkurang dan kerabang telur menjadi tipis dan lembek. Oleh hal itu topografi sangat bepengaruh nyata terhadap ketebalan kerabang. Hal ini sesuai dengan Oguntunji dan alabi (2010) meyebutkan bahwa kualitas kerabang telur yang rendah pada suhu lingkungan yang tinggi $\left(>32^{\circ} \mathrm{C}\right)$ juga disebabkan oleh rendahnya konsumsi pakan ayam sehingga konsumsi pakan menurun pada suhu tinggi sehingga nutrien yang diperoleh rendah.

\section{pH Telur}

Berdasarkan analisis sidik ragam menunjukkan bahwa umur ayam yang berbeda berpengaruh nyata $(\mathrm{P}<0,05)$ terhadap kadar $\mathrm{pH}$ telur dapat di lihat pada gambar 3 . Sedangkan topografi berpengaruh sangat nyata $(\mathrm{P}<0,01)$ terhadap kadar ph telur telur dapat dilihat pada gambar 4 . Interaksi antara keduanya tidak berpengaruh nyata $(\mathrm{P}>0,05)$ terhadap $\mathrm{pH}$ telur.

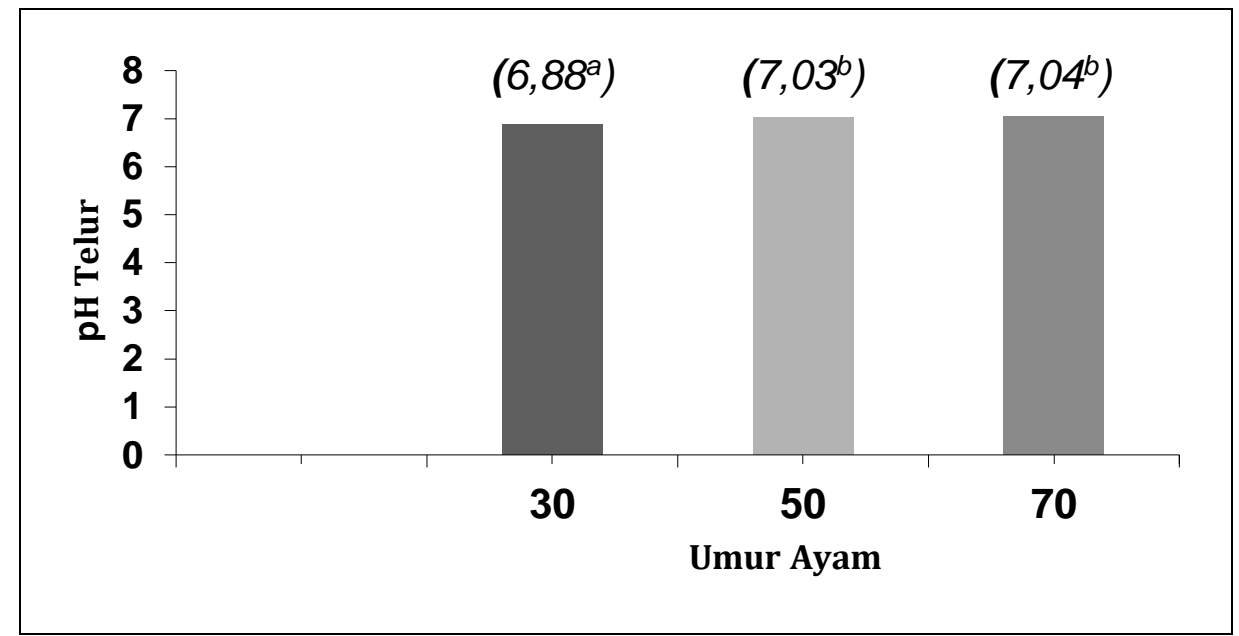

Gambar 3. Kadar pH Telur Ayam Ras dengan Perlakuan Umur yang Berbeda $(A 1=30$ Minggu, A2=50 Minggu, A3=70 Minggu)

Gambar 3 menunjukkan perbedaan umur ayam ras yang berbeda berpengaruh nyata $(\mathrm{P}<0,05)$ terhadap kadar $\mathrm{pH}$ telur. Kadar $\mathrm{pH}$ telur pada umur ayam yang berbeda berada berkisar antara 6,88 sampai dengan 7,04. Kadar ph telur umur 30 minggu (6,88), 50 minggu $(7,03)$ dan 50 minggu $(7,04)$.

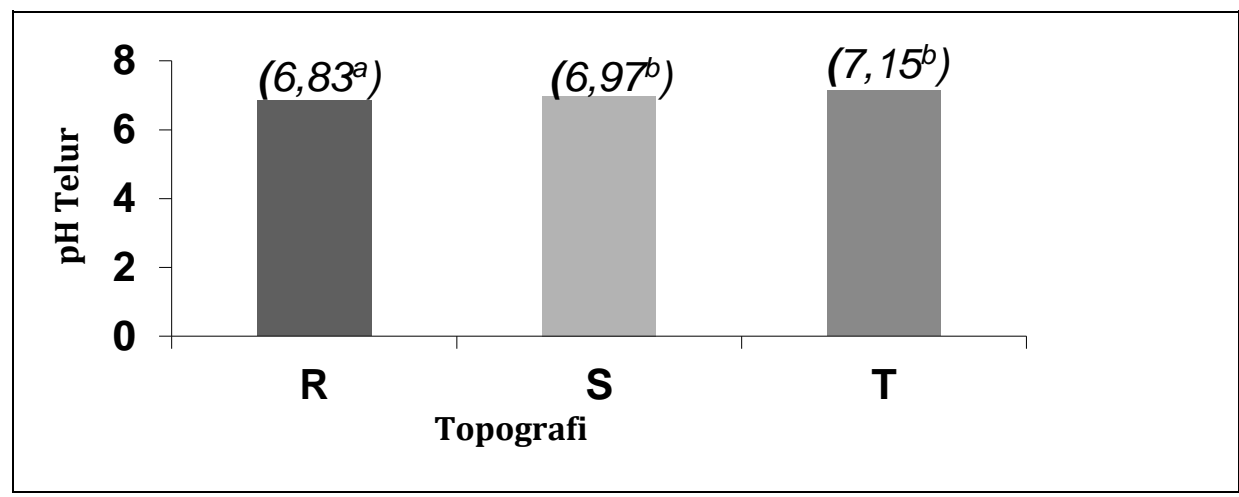

Gambar 4. Kadar pH Telur Ayam Ras dengan Perlakuan Topografi yang Berbeda (R=Dataran Rendah, $S=$ Dataran Sedang), $T=$ Dataran Tinggi). 
Gambar 4 menunjukkan topografi yang berbeda berpengaruh sangat nyata $(\mathrm{P}<0,01)$ terhadap kadar $\mathrm{pH}$ telur. Kadar $\mathrm{pH}$ telur pada topografi yang berbeda berada berkisar antara 6,83 sampai dengan 7,15 . Kadar ph telur pada dataran rendah $(6,83)$, dataran sedang $(6,97)$, dan dataran tinggi $(7,15)$.

Derajat keasaman $(\mathrm{pH})$ telur tergantung pada kondisi penyimpanan telur.pH telur berkisar 7,6 -7,9, hal ini sesuai dengan pendapat Belitz (2009), pH telur yang baru dikeluarkan atau telur segar kira-kira 7,6-7,9 dan meningkat sampai nilai maksimal 9,7 tergantung temperatur dan lama penyimpanan. Keluarnya $\mathrm{CO}_{2}$ melalui pori-pori kerabang telur meyebabkan penurunan pH. Hal ini sesuai dengan pendapat Rizal $d k k$ (2012) pH albumin meningkat karena disebabkan oleh lepasnya $\mathrm{CO}_{2}$ melalui pori-pori cangkang. Putih telur yang mempunyai pH meningkat menjadi basa selain disebabkan oleh menguapnya $\mathrm{CO}_{2}$, disebabkan karena putih telur dibagian yang kental mengalami pengenceran yang akhirnya akan merembes ke kuning telur.

Suhu pada penyimpanan telur dapat mempengaruhi $\mathrm{pH}$. Sesuai pendapat Agustina $d k k$ (2013), suhu dapat mempengaruhi pH putih dan kuning telur. Semakin tinggi suhu makan $\mathrm{CO}_{2}$ yang hilang lebih banyak sehingga menyebabkan $\mathrm{pH}$ putih dan kuning telur meningkat. Telur segar adalah telur yang masih memiliki kadar pH normal, yaitu 7, apabila kadar $\mathrm{pH}$ lebih dari 7 berarti telur sudah beberapa hari tersimpan. Telur yang lama disimpan dapat turun kualitasnya diakibatkan penguapan dalam telur sehingga isi telur menjadi lebih encer.

\section{Kesimpulan}

Berdasarkan hasil dan pembahasan dapat disimpulkan sebagai berikut. Umur ayam dan topogarfi dapat mempengaruhi ketebalan kerabang telur ayam ras. Pada umur ayam semakin tua kualitas kerabang telur menurun dikarenakan ayam semakin tidak mampu untuk memproduksi kalsium. Sedangkan topografi mempegaruhi ketebalan kerabang dikarenakan setiap peningkatan suhu meyebabkan menurunnya konsumsi pakan sehingga kualitas kerabang semakin berkurang.

pH telur pada saat pengambilan data normal pada kisaran 7, hal ini dikarenakan telur langsung diambil dan diteliti pada saat itu jaga. Perubahan $\mathrm{pH}$ terjadi apabila sudah lebih dari 1 hari penyimpanan dan terjadi perubahan suhu, sehingga kadar $\mathrm{pH}$ telur meningkat.

\section{Referensi}

Agustina, N., Imam, T \& Djalal, R. (2013). Evaluasi Sifat Putih Telur Ayam Pasteurisasi Ditinjau dari pH, Kadar Air, Sifat Emulsi dan Daya Kembang Angel Cake. Jurnal Ilmu-Ilmu Peternakan, 23 (2), 6-13.

Belitz, H.D. \& W. Grosch. (2009). Food Chemistry. Second Edition. Springer Berlin. Berlin.

Buckle, K. A., R.A. Edward, W.R. Day, G. H. Fleet \& M. Wotton. (1987). Ilmu Pangan. Universitas Indonesia Press. Jakarta. (Diterjemahkan oleh Hadi Purnomo dan Adiono).

Haryono. (2000). Langkah-Langkah Teknis Uji Kualitas Telur Konsumsi Ayam Ras. Temu teknis Fungsional non Peneliti. Balai Penelitian Ternak. Bogor.

Indratiningsih dan Rihastuti., (2006). Kualitas Telur. Jakarta. Penebar Swadaya.

Oguntunji, A.O. \& O.M. Alabi. (2010). Influence of High Environmental Temperature on Egg Production and Shell Quality. A Review. World's Poultry Science Journal, 66, 739-750. 
Rizal. B, A. Hintono, dan Nurwantoro. (2012). Pertumbuhan Mikroba pada Telur Pasca Pasteurisasi. Anim Agri J, 1 (2), 208- 218.

Romanoff, A. I. \& A. J. Romanoff. (1963). The Avian Egg. Jhon Willey and Sons. Inc, New York.

Winarno, F. G. dan S. Koswara. (2002). Telur: Komposisi, Penanganan, dan Pengolahannya. MBrio Press. Bogor.

Yuwanta, T. (2010). Telur dan Kualitas Telur. Gadjah Madja University Press, Yogyakarta.

\begin{tabular}{|l|ll|}
\hline Andika Dony Wijaya & $\begin{array}{l}\text { Program Studi Peternakan/Fakultas Pertanian, Peternakan dan } \\
\text { Perikanan. Universitas Muhammadiyah Parepare } \\
\text { E-mail: } \underline{\text { dhika8jaya@gmail.com }}\end{array}$ & \\
\hline Munir & $\begin{array}{l}\text { Program Studi Peternakan/Fakultas Pertanian, Peternakan dan } \\
\text { Perikanan. Universitas Muhammadiyah Parepare } \\
\text { E-mail: } \underline{\text { dhika8jaya@gmail.com }}\end{array}$ & \\
\hline Muh. Jurhadi Kadir & $\begin{array}{l}\text { Program Studi Peternakan/Fakultas Pertanian, Peternakan dan } \\
\text { Perikanan. Universitas Muhammadiyah Parepare } \\
\text { E-mail: } \underline{\text { dhika8jaya@gmail.com }}\end{array}$ & \\
& & \\
\end{tabular}

